\title{
Istanbul International Film Festival 2012
}

\author{
By Gönül Dönmez-Colin
}

Fall 2012 Issue of KINEMA

ISTANBUL 2012

April was the cruellest month of the year for Istanbul this spring, with incessant rains and cold weather, which increased the attendance figures at the cinemas. The festival (31 March-15 April, 2012) celebrated its 31st anniversary with an eclectic program of features and documentaries, relying heavily on European products as customary, except for a martial arts package, the Chinese wuxia films. Due to its belated date in the festival calendar, Istanbul suffers from paucity of new films, but it is a feast for the local cinephiles with its wide spectrum of selections including feature films of the year, classics, masterpieces from masters, festival favorites, National Golden Tulip, International Golden Tulip and FACE Human Rights Competitions, documentaries, and children's movies. This year's additions were Cinema and Music, Filming Revolution, What's Happening in Greece?, Within the Family and a 15-hour special view of Mark Cousins's The Story of Film: An Odyssey. The foreign guests, who are invited for only the second half of this two-week bonanza, mostly follow the local films.

The international competition is comprised of films about the arts and the artist, or adaptations from literary works. This year's entries, which included Andrea Arnold's Wuthering Heights (adapted from Bronte's novel published 165 years ago), Robert Guediguian's Snows of Kilimanjaro (a reference to Pascal Danel's song) and Cut, the Iranian exile Amir Naderi's nostalgic salute to cinema, shot in Japan, did not force the jury into laborious deliberations according to the jury president, Nuri Bilge Ceylan and the decision was made in five minutes unanimously to choose a film that Ceylan admitted has given answers to some of his personal questions regarding a better understanding of himself and he was 'surprised' that it was actually made by a woman. The film that impressed Ceylan so much and received the Golden Tulip was Julia Loktev's The Loneliest Planet, about a couple's doomed voyage in the Caucasian mountains.

The most awaited film in the national competition was Zeki Demirkubuz's Yeraltı (Inside) liberally adapted from his bedside author Dostoevsky's Notes From the Underground. Taking place in the present time, the film presents a Kafkaesque character whose righteousness, self-loath and destructive pride dissociate him from society. While he disdains the superficiality of his friends, he is shunned by them for his false pride and his failure to succeed. His adversary, a well-known writer, who made his fame with a novel called Ankara

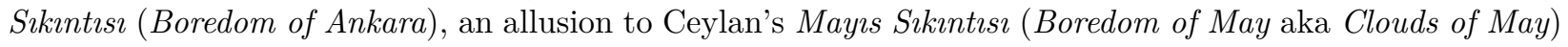
steals other's ideas, he claims.

Akin to previous Demirkubuz work and harmonious with the director's reputation as the 'angry young man' (who has now reached middle age), the film was perhaps the most accomplished work in the program with its professional mise-en-scène and remarkable acting. A new-comer's excellent rendition of Turkish politics and the Turkish psyche, which always blames 'the enemy inside, the enemy outside' for all mishaps, Tepenin Ardı (Beyond the Hill) which has already been awarded at the Berlin Film Festival drew the attention of the discerning viewers right away along with $I z$ - rêç (The Trace), whose director, unlike Emin Alper, a university professor, is a young Kurd from the east.

The story of a stubborn old man who wants to bury his mother in her natal village as he had promised, despite the ongoing war and the reluctance of his young son who prefers to Turkify himself to be accepted by his peers, the film's cinematography showing the wide spaces of Anatolian plains like in American westerns and particularly the shots of the coffin pulled on a suspension bridge that never seems to reach the other side were spectacular, the burden getting heavier as the two characters delve into the dark corners of their psyche. The eventual revelation of the true identity of the grandmother who perhaps symbolized all the pains of the people of Anatolia was masterfully crafted.

A well-constructed film on one of the most shameful traditions in Turkey, which is in active force today, the child brides given to older man, created much controversy despite its good intentions. Most of Lal Gece (Night of Silence by Reis Çelik) takes place in a bridal chamber where a fourteen-year-old girl devises countless schemes to delay the consummation of her marriage to a man in his late fifties. Just like the 
previous films of Çelik which often end with a socio-political message, Night of Silence, which begins from the point of view of the bride, shot through her red veil, soon turns the camera to the male, lamenting the fate of men, the victimizer as the victim, in a capitalist system that considers human beings as merchandise to be bought and sold.

According to some of the women in the audience following its Turkish premiere, the film 'normalizes' a very serious issue. Lingering of the camera on the girl's beautiful face was perhaps a bit voyeuristic and the all night dialogue between the couple hardly realistic although the 'chamber film' style manouvering in a tight space, a rarity in Turkish cinema was masterfully handled. Most critics agreed that Can, which had received the Special Jury Prize at the Sundance Film Festival was a disappointment. Neither the script nor the acting lived up to expectations in this melodrama that used several clichés of the commercial Turkish cinema of the 1960s-1980s, known as Yeşilçam.

With the easing of the language restrictions, more films are made in Turkey in the languages of the minorities, and in addition to The Trace, Babamın Sesi (Voice of My Father by Orhan Eskiköy and Zeynel Doğan) and Ana Dilim Nerede? (Where is My Mother Tongue? by Veli Kahraman) also foregrounded the issues of the Kurdish people and their anxieties about preserving their culture and traditions.

Among the master classes held during the festival, next to jury member award winner Philippine director Brillante Mendoza and another award winner Terence Davies, Turkey's own, Nuri Bilge Ceylan captured the audience interest (mostly film students) with his candid sharing of the trials and tribulations of filmmaking.

The closing film was the Golden Bear-winner Caesar Must Die by Paolo and Vittorio Taviani.

\section{References}

\section{Awards}

Golden Tulip International Competition Award

The Loneliest Planet (Julia Loktev)

Golden Tulip International Competition (Special Jury Prize)

Oslo, August 31st (Joachim Trier)

Golden Tulip National Competition Best Picture

Beyond the Hill (Emin Alper)

Golden Tulip Best Director of the Year

Inside (Zeki Demirkubuz)

Special Jury Prize

The Trace (M. Tayfur Aydin)

Best Actress Award

Sanem Öge, Present Tense

Best Actor Award

Engin Günaydın, Inside

Best Screenplay Award

Beyond the Hill (Emin Alper)

Voice of My Father (Orhan Eskiköy)

Best Director of Photography Award

Türksoy Gölebeyi, Inside 
Best Soundtrack Award

Mustafa Biber, The Trace

Best Editing Award

Zeki Demirkubuz, Inside

FIPRESCI Award International Competition

Wuthering Heights (Andrea Arnold)

FIPRESCI Award National Competition

Beyond the Hill (Emin Alper)

Human Rights in Cinema Competition Face Award

Just the Wind (Bence Fliegauf)

People's Choice Award International Competition

Albert Nobbs (Rodrigo Garcia)

People's Choice Award National Competition

Inside (Zeki Demirkubuz)

\section{Author Information}

Gönül DÖNMEZ-COLIN is an independent researcher and writer whose publications include Women, Islam and Cinema, Cinemas of the Other: A personal Journey with Filmmakers from the Middle East and Central Asia, Cinema of North Africa and the Middle East (ed.); Turkish Cinema: Identity, Distance and Belonging (Reaktion Books), and Routledge Dictionary of Turkish Cinema (2014). 